\title{
Tear Down What Wall? Undefined Borders and the Assertion of Soviet Space in Greater Siberia, 1917-1935
}

\author{
Jonathan Bone \\ William Paterson University, Wayne, New Jersey, USA
}

\begin{abstract}
Militarization in the Soviet Far East in the 1930s - part and parcel of its Stalinist transformation into a garrison province qua prison - was driven by external events in Northeast Asia. Japanese economic and military expansion, specifically the investiture of Manchuria in 1931, precipitated a crash reversal of the New Economic Policy (NEP) paradigm in the Far East that until then had governed border policies. Hitherto unknown Politbiuro-level plans show that Stalin and his planners deliberately sought long-term qualitative superiority (modern, mechanized forces) to counter quantitative inferiority. The paper gives details of the ultra-secret, seminal orders: massive troop and equipment relocations (by the end of 1932, one ninth of the Red Army was east of Lake Baikal); crash construction of fortifications; etc. However, it goes further. It investigates the extent to which industrial and infrastructure development in the Far East were driven by military considerations, and relied on Gulag labor for completion. By 1934, roughly $60 \%$ of the Union-level capital investment in the region had direct or secondary military significance. This is far higher than generally recognized. Since all this had ripple effects throughout the entire USSR, it challenges the Sovietological consensus that threats from the West (especially Nazi Germany) were what prompted the Stalinist militarization drive.
\end{abstract}

Keywords: Stalin, Soviet Union, 1930s, Far East, militarization, GULAG, Japan, Manchuria

\section{Introduction}

In his dystopian classic Moscow 2042, the novelist Vladimir Nikolaevich Voinovich envisioned the future of the Soviet Union - had it continued to slouch towards utopia, along the path he believed it had been following (Voinovich, 1987).

One of the funniest of the novel's many time-travel jokes is the idea that in the year 2042, 125 years after the October Revolution, socialism has actually been achieved within Russia. But not "socialism in one country", as Stalin's well-known formula had defined ambition in the 1920s. Rather, the Bolsheviks in Voinovich's dark vision have ultimately managed to achieve socialism in one city. Specifically in Moscow, whose socialist space has been separated from non-socialist space by an 18-foot-high facsimile of the Berlin Wall.

Within the barbed wire-and-ferroconcrete perimeter are three concentric zones. Their levels of political acculturation and corresponding privilege decrease with residential distance from the city center. And according to Voinovich, orderliness in this system has been achieved by shifting socialists into their appropriate zones while exiling anti-socialist undesirables. The latter are consigned to the supposed stikhiinost ${ }^{\text {, }}$ on the

Jonathan Bone, Assistant Professor, Department of History, William Paterson University.

${ }^{1}$ Literally, "spontaneity" understood extremely pejoratively during the Soviet era. 
other side of the municipal border-stikhiinost' which includes such wild and barbarous locales as Riazan and Kaluga.

I mention this anecdote not to go off on a tangent about Voinovich the dissident, nor do I suggest anything like an exact parallel between the blackly humorous future he imagines, the Berlin Wall, and the Stalinist approach to Dal'nevostochnyi krai (the Soviet Far East, henceforth DVK) in the 1920s and 1930s. Still, I would like to suggest that in keeping with the Russian satirical tradition as pioneered by Gogol, there's more to the Voinovich alternate universe than mere lampoon.

I take Voinovich's point to be that a three-way: Mutually constitutive relationship exists between the conceptualization/reconceptualization of Stalinist space (cf. the constantly evolving idea of socialism in one city); Bordering of that space (cf. the construction of physical perimeter walls); Social engineering of that space (cf. the coercive "filtration" of fellow travelers and the exclusion of undesirables).

Particularly in the study of the Soviet Far East, I would tentatively suggest for the study of the Stalinist Soviet Union in general, I believe we ignore Voinovich's mutuality at our peril. Without meaning to imply that his three implicit categories carry equivalent explanatory potential, I nevertheless want to suggest that it is impossible to understand the history of the Soviet Far East's incorporation into the USSR without taking into account not only all three categories but feedback between them. ${ }^{2}$

In the case of the DVK, such study is not well served by existing theoretical literature, either on the region's history or on Soviet borders in general. None of it offers much that bears directly on the situation. However the DVK's pre-World War II, Stalinist makeover is well described by the conceptualization, formation and consolidation of external borders so as to facilitate the colonization of internal frontiers. Part of what eventually will be a comprehensive look at the Stalinist Revolution in the region, this paper argues that external events in Northeast Asia, especially those connected to Japanese economic and military expansion in Manchuria and northern China, precipitated a crash reversal of the New Economic Policy (NEP) paradigm in the Far East that until then had governed border policies.

\section{Soviet Far Eastern Security in the 1920s}

Although the Russian Civil War had more or less played itself out in most of the former Tsarist Empire by the end of 1920, it was not until October 1922 that Japanese intervention forces pulled out of the southern part of the DVK mainland (they would remain on northern Sakhalin and in Kamchatka until the end of 1924-start of 1925). Their withdrawal opened the way for advancing Red forces, whose capture of Vladivostok on October 25, 1922 prompted remaining White forces to retreat to comparative safety in Manchuria. On the morning of October 26, the Bolsheviks began to wake up to the realization that they had inherited Imperial Russia's sphere of influence in northeast Asia rather than meaningfully delineated borders. No one in fact really knew just where nominal Soviet space ended and whatever lay beyond it began. Mapping under Tsarist governments had begun late and been conducted sporadically, and while there were words in various treaties and lines on sundry maps associated with them, nothing was distinguished with much on-the-ground resolution.

To be sure, this did not bother the mid-1920s Bolshevik leadership overmuch. Both Lenin and the dominant faction in the Council of Labor and Defense (STO, for Soviet trudy i oborony; the Union-level

\footnotetext{
${ }^{2}$ I follow here Nick Baron's 2008 call for a "new spatial history" characterized not so much by unifying ideology or methodology but by focus, namely a "shared critical interest in the interaction of space with human agency and the mediating role of culturally defined spatial practices in history" (Baron, 2008).
} 
strategic-defense council), understood the situation in transnational terms involving friction between capitalism and socialism. Policy in the Far East therefore focused on holding Chinese warlords, a motley collection of mountebanks, poachers, bandits, smugglers, expatriate-Russian White Guardists, and other lightly armed threats under control on the Korean-Manchurian-Mongolian side of things. NEP doctrine (to the extent there was one rather than seat-of-the-pants flying) suggested that Soviet domination of the meager "commanding heights" in those areas - especially the Chinese Eastern Railway-was a cost-effective way to keep them from becoming militantly capitalist. And as long as they were in flux, they represented long-term possibilities rather than near-term existential threats.

The general thrust of this policy-by-lack-of-a-better-alternative is perhaps best illustrated by comments made in Mongolia in 1929 by a Comintern representative: The territory of Mongolia is of great international significance. Although its population is no more than 800,000 , its territory is bigger than Britain, Germany and France combined. Our main purpose is to maintain our dominant influence in that vast territory in order not to let Mongolia slip into the sphere of imperialists and enemies of the world revolution. That purpose is much more important than building socialism in a country of 800,000 cattle breeders (Batbayar, 2003).

\section{Storm Clouds Gather}

By the spring of 1931, however, Council of Labor and Defense chair Alexei Rykov and other like-minded "rightists" who subscribed to this relatively laissez-faire, "fuzzy frontier" vision of the USSR in Asia had been purged from policy/planning posts. Not only was the threat assessment beginning to change under the Soviet Union's new dictator, Joseph Stalin, so too was the general responsiveness of its industrial establishment to military procurement demands (Samuelson \& Shlykov, 2000; Stone, 2000).

Aware of the vulnerability of the thousands of miles of virtually undefended northern and Far Eastern shoreline, Stalin pushed through Politbiuro authorization for a drive to build a numerically substantial, if not very imposing Soviet coastal-defense fleet by no later than 1935: 200 to 250 small submarines, 40 to 50 destroyers, 150 to 200 torpedo boats, etc. In July 1931, the loyally Stalinist Defense Commissar Kliment Voroshilov was even dispatched to Siberia and the Far East to review personally the state of their defenses and survey the possibilities for further improvements along these lines (Kvashonkin, 1999, pp. 154-156, 161). However these measures cannot be described as anything yet like a comprehensive military buildup. Nor do they seem to have been a reaction to any specific threat or even suspicion.

Absent candid stenographic records of Red Army General Staff sessions and/or meetings in Stalin's office, neither of which seem to exist, it is impossible to do more than surmise at the strategic assessment behind these actions. Still, they give every appearance of a temporary Stalinist fix for a long-running problem facing first late-Imperial Russia and latterly the USSR in Asia. Rather crudely, it boiled down to lots of Asians potentially fighting in their near-abroad versus a comparatively small number of Russians/Soviets fighting at the end of the extremely tenuous ribbon represented by the Trans-Siberian Railway and its connecting lines.

This "yellow peril" problem had imperiled Tsarist operations in the Russo-Japanese War; while much attention was given at the time (and later) regarding the difficulties of transporting ground forces from their staging points in European Russia to distant Korean-Manchurian battlefields, naval considerations also came into play. The point was that Japanese regulars also had needed delivery to the fighting. They didn't have to cross thousands of miles of Siberian wilderness by very slow, and around Lake Baikal, discontinuous rail connections. But they did have to cross over from the Japanese Home Islands to the Northeast Asian mainland. 
As long as Russian naval forces credibly threatened their crossing en masse, Japan would have to make do with much the same sort of logistically challenged expeditionary force.

Hence the surprise attacks on the Russian Pacific Fleet that launched hostilities in 1905: the novelty of torpedo-boat attacks combined with old-fashioned battleship gunfire to sink or render wholly impotent virtually every Tsarist naval vessel in the Far East in the first hours of battle. Their pitiful fate allowed the Japanese to ferry over - in rented British hulls - the full-scale army that took the supposedly impregnable fortress of Port Arthur from the landward side. And it was a desperate attempt at interdicting reinforcements that prompted the subsequent silly dispatch of the Baltic fleet more than halfway around the world, to be sunk ignominiously at Tsushima.

Whether or not the Tsarist Army learned anything from the above, the lesson Stalinist planners took from the Russo-Japanese war was that in the event of serious friction with Japan, credible threats to troop movements from their island bases to the mainland might prove a powerful deterrent. And even if they didn't deter aggression completely, they might well bring the Red Army forces in the region much closer to parity than would be the case given unimpeded reinforcements.

Although this reasoning was fairly straightforward, its policy-planning implications were actually fairly daunting. The Soviet Union had entered existence in 1922 with precisely one naval vessel of any sort in Far Eastern waters, an antiquated coast-guard cutter named the Whympel. It was barely capable of venturing out of sight of land, let alone challenging a Japanese battle fleet that was probably second-strongest in the post-World War One world (Stephan, 1994). And since literally nothing had been done since then to rectify the situation, Stalin and his strategists hit upon the torpedo as the most expedient (and cheapest) naval deterrent.

The technological and material challenges of building battleships for the Far East (let alone aircraft carriers, which the navies of the world were just starting to take seriously) looked to be a good decade from solution under the best of circumstances. Torpedo attacks, moreover, required much less of a leap for the nascent Red Navy. Torpedo boats were nothing more than fast motorboats with a crude launching system. They easily could be built of wood in the Far East with the engines shipped in by rail. As for submarines, which the Imperial German Kriegs marine had proven a deadly threat to Great Britain in the First World War, the Stalinist solution was to buy a small surplus U-Boat that the Germans weren't supposed to have had, reverse-engineer it in the Baltic Navy Yards, mass-produce Soviet versions there, and ship them partly assembled by rail to the Far East for deployment.

\section{The Japanese Investiture of Manchuria}

The measures outlined above might have been sufficient, had militarists in the Kwangtung Army not forced matters in 1931. Beginning with the so-called Mukden Incident on September 18, 1931, their investiture of Manchuria dramatically upped the ante by presenting the clear and present danger of invasion along more than 1,000 miles of newly vulnerable land border. Publicly, the Soviet Union responded by condemning the action in the press while repeatedly avowing its intention to stay out of what it billed as a Japanese-Chinese conflict. It repeated this line in diplomatic exchanges with Japan that (among other pointedly symbolic, tension-diffusing results) led to a convention on postal deliveries and the opening of negotiations on a new fisheries convention (Kvashonkin, 1999, p. 163). However behind this facade of cooperation the Stalinist leadership scrambled feverishly to find ways to counter the new menace to the Far East.

The experience of the Bliukher Expedition in 1929, in which the Red Army conducted punitive operations 
in Manchuria against Chinese forces, had highlighted both the military difficulties of repelling multiple incursions into Soviet space and the huge manpower disadvantages Soviet forces faced in comparison to their likely Asian foes. ${ }^{3}$ Thus the Stalinist military response to the overland Japanese threat proposed perimeter defense-in-depth: frontier fortifications designed to slow up an attacking enemy, backed by a mechanized counter-attacking force that could be shifted rapidly from point to threatened point (Stoecker, 1998). To put this rather crudely, Stalin, the leading Red Army strategist Marshal M. N. Tukhashevskii and the rest of the General Staff instinctively sought qualitative superiority as a way of countering quantitative inferiority along their border.

Based on these considerations, the new Stalinist response to the Manchurian investiture entailed massive increases in the size, budget, and equipment of the special standing army (OKDVA) committed to the region. The basic blueprint for this was hammered out over the winter break between 1931-1932 in a seminal, 39 page document so secret that only three copies ever seem to have existed. Stalin held one; one was archived with the General Staff; and the third was given to Stalin's main plenipotentiary for the Far East, former regional satrap and latterly head of the Red Army's Political Administration Ian Gamarnik. To my knowledge, the only reference to this document in print in English is a brief mention in David Stone's otherwise completely excellent Hammer and Rifle: The Militarization of the Soviet Union, 1926-1933. Evidently basing his assessment on another passing reference in a mid-1990s Soviet article, whose author may not have seen the original document either, Stone notes only “... the [Politbiuro] Defense Commission strengthened the Special Red-Banner Far Eastern Army (OKDVA) with additional troops and equipment, along with further fortifications and bases in the Far East" (Stone, 2000, p. 187). Quite inadvertently, this nevertheless grossly misrepresents the actual scope of the measures.

\section{The Politburo Responds to the Japanese Threat}

I give the bulk of it here in condensed form, so as to demonstrate incontrovertibly the extent to which the Japanese advance prompted a complete reversal of prior thinking about the limits of Soviet space in Northeast Asia:

(1) Red Army Units Ordered Transferred To The Far East In January-February 1932;

(a) Four fully mobilized rifle divisions (12th, 21st, 40th, 57th ${ }^{4}$ );

(b) Two tank battalions from Moscow, each with three tank and one tankette companies: One battalion of 55 MS- 1 tanks, ${ }^{5} 21$ tankettes, and six armored cars;

(c) One battalion of $31 \mathrm{~T}-26$ tanks, ${ }^{6} 21$ tankettes, and seven armored cars;

(d) Three artillery units from the Main Command Artillery Reserve: One detached from the Third Corps Artillery Regiment in Riazan (Moscow Military Region), with two $107 \mathrm{~mm}$ cannon and one $152 \mathrm{~mm}$ howitzer

\footnotetext{
${ }^{3}$ Little has been written on this trans-border conflict involving extended Soviet interests in central Manchuria. The most recent, best work is (Patrikeeff, 2010).

4 The 57th Rifle Division was actually ordered into the Far East by no later than 15 March 1932.

5 The MS-1, also known as the T-18, was based on a reverse-engineered Renault model and in 1927 became the first Soviet production tank. The 55 assigned to the Far East probably represented about one-eighth of the total in Red Army service at the time. For more see the Military Factory web-page on the T-18 (MS-1) Light Tank. Retrieved June 2, 2015, from http://www.militaryfactory.com/armor/detail.asp?armor_id=307

6 The T-26, licensed from Vickers, began production in the spring of 1931 and only entered Soviet service that September. The 31 assigned to the Far East in January 1932 represented a considerable portion of the Red Army's contingent at the time. For more see the MilitaryFactory web page on the T-26 Infantry Light Tank. Retrieved June 2, 2015, from http://www.militaryfactory.com/armor/detail.asp?armor_id=254
} 
batteries; One detached from the 108th Artillery Regiment in Bronipa (Moscow Military Region), with one $122 \mathrm{~mm}$ and two $152 \mathrm{~mm}$ howitzer batteries; One detached from the 104th Artillery Regiment at Detskoe Selo (Leningrad Military Region), with two $107 \mathrm{~mm}$ cannon batteries and one $152 \mathrm{~mm}$ howitzer battery;

(e) One chemical-warfare battalion from the First Chemical Regiment (Iaroslavl'); One communications battalion from Tomsk (Siberia Military Region); One radio company, from the First Radio Regiment (Vladimir); One sapper company from the First Sapper Battalion (Nakhabino); One railroad-artillery division from Peterhof (Leningrad Military Region), with two 203mm, four $152 \mathrm{~mm}$, and two $130 \mathrm{~mm}$ guns; One armored-train unit (three trains) from Polotsk;

(f) Two field-antiaircraft divisions, one from Moscow and one from Krasnogvardeisk (total of 24 weapons);

(g) One anti-aircraft division from Pskov (12 guns, 12 heavy machine guns and six searchlights);

(h) Two field-artillery support units, one for Irkutsk and one for Khabarovsk.

To these ground forces were to be added seven more anti-aircraft divisions (21 batteries totaling 8476.2 mm guns), to be readied by May 1, 1933 for dispersal between Khabarovsk, Vladivostok, Nikol'sk-Ussuriisk and De Kastri Bay.

(2) New Shore Defenses Ordered Built In 1932-1933;

(a) Vladivostok ${ }^{7}$

- Four $152 \mathrm{~mm}$ batteries (total of 16 guns), by 15 March 1932;

- One 305mm howitzer battery (four guns), by 1 April 1932;

- One railroad-artillery division with two 203mm, four $152 \mathrm{~mm}$, and two $130 \mathrm{~mm}$ guns, by 1 March 1932;

- One 356mm railroad-artillery battery (three guns), by 11 December 1932;

- Two 305mm railroad-artillery batteries (eight guns), by 1 April 1933;

- Three $180 \mathrm{~mm}$ turret batteries (12 guns), by 1 May 1933;

- Four $152 \mathrm{~mm}$ self-propelled batteries (12 guns), by 1 May 1933. Two 305mm turret batteries (six guns), by 1 July 1933.

(b) De Kastri Bay

- One 120mm battery (four guns), by 1 April 1932;

- One $152 \mathrm{~mm}$ battery (four guns), by 1 April 1932;

- One 152mm battery (four 1909/1930-model guns), by 1 April 1932;

- One 180mm turret battery (four guns), by 1 May 1933;

- Two $152 \mathrm{~mm}$ self-propelled batteries (six guns), by 1 May 1933.

(c) Amur River Estuary ${ }^{8}$

- Two 120mm batteries (six guns) from those in Vladivostok warehouses;

- One $152 \mathrm{~mm}$ battery (two guns), within 15 days of the opening of the Amur;

- One $152 \mathrm{~mm}$ battery (four guns), by 1 May 1933.

(d) Petropavlovsk-na-Kamchatka

- One $107 \mathrm{~mm}$ battery (three 1910/1930-model guns), by 1 May 1932;

- Aleksandrov-na-Sakhaline;

\footnotetext{
7 Vladivostok was already protected by eight $120 \mathrm{~mm}$ guns left over from the Imperial era, which were to be re-sited.

8 The Amur River's mouth was already protected by two $152 \mathrm{~mm}$ guns, again relics of the late Imperial era, which were to be re-sited.
} 
- One 107mm battery (three 1910-model guns), by 1 May 1932;

- Cape Srednyi and Cape Pobeda;

- One open $152 \mathrm{~mm}$ battery each (eight guns), by 1 May 1933.

(3) New Aviation Units, 1932-1933.

(e) Khabarovsk

- One air brigade consisting of two heavy-bomber squadrons (24 TB-3 planes) and one cruising squadron (12 multipurpose P-5 planes).

- (f) Chita

- One fighter squadron (15 I-5 biplanes)

The goal was to boost active-duty air strength to 133 planes by the end of 1932, including the transfer of ten planes of the Sixth Squadron in Novosibirsk and twelve of the 51st Squadron in Omsk.

(4) New Fortifications.

Table 1

Location of New Fortifications

\begin{tabular}{ll}
\hline Location & Bunkered Entrenchments \\
\hline Vladivostok & 14 \\
Grodekovo & 18 \\
Suchan & 3 \\
De Kastri Bay & 4 \\
Ust-Amurskii District & 4 \\
Ust-Sungariiskii District & 2 \\
Ust-Ussuriiskii & 2 \\
Blagoveshchensk & 12 \\
Trans-Baikal Territory & 15 \\
Total & 75 \\
\hline
\end{tabular}

At least 25 of these were ordered completed in 1932, their locations to be determined by Gamarnik in conjunction with the command staff of the Special Red-Banner Far Eastern Army.

(5) New Command Posts;

These were to be constructed at Vladivostok, Khabarovsk, Nikol'sk-Ussuriisk, Grodekovo, Blagoveshchensk, Bochkarevo, Petropavlovsk-na-Kamchatke, Aleksandrov-na-Sakhaline, Nikolaevsk-na-Sakhaline, and Nikolaevsk-na-Amure.

(6) Strengthening the Mongolian People's Army;

By 15 March 1932, the Commissariat of Defense was ordered to send to Ulaanbaatar 70 heavy and 150 light machine guns; Eighteen 76mm guns; one tank company (15 tanks); five Ford light armored cars; and six obsolescent planes. It was also to organize a pilot-training school in the Mongolian capital.

(7) Boosting the Border Forces;

The Politbiuro Defense Commission ordered the OGPU force assigned to guard the Lake Baikal tunnels and other vulnerable spots on the Trans-Baikal and Ussurii Railroads increased by 1,500 men. The Border Patrol (pogranokrana OGPU) in Western Siberia was ordered increased to 2,400 men and 2070 horses, and in the Far East to 5,250 men and 2,400 horses. Strengthening of the border was to take place in the Dauriia, Nerchinsk, Blagoveshchensk, Khabarovsk, and Vladivostok districts, as well as at the harbor of Sovetskaia 
Gavan. In addition, Border Guard regiments of 1,500 men each were to be formed for Sakhalin and Kamchatka. (10) General Buildup of Defense Capability.

\section{Commissariat of Railroads}

The Defense Commission gave Railroad Commissar A. A. Andreev 20 days to develop a plan for boosting the wartime capacity of the vital rail connections to the Far East. He was instructed to reconfigure the partly double-tracked line between Achinsk (west of Krasnoiarsk, on the Tomsk railway) and Karymskaia (just east of Chita) to handle 48 military-schedule trains per day in each direction. Within the Far East proper, he was to give the mostly single-tracked, signal-free stretch from Karymskaia to Nikol'sk-Ussuriisk a capacity of 24 trains (which would more than double its existing limit). Andreev was instructed to give materials and equipment for this highest possible priority, above any and all other projects. Finally, he was to create powerful "locomotive parks" (the railroad equivalent of motor pools) on the Tomsk, Trans-Baikal, and Ussurii railroads by 1 March 1932 .

\section{Central Highway and Vehicle Administration}

This highway-construction and trucking trust was ordered to build or finish a total of 676 kilometers of roads, ranging from a 12-kilometer trifle between Khabarovsk and its airport to a $372 \mathrm{~km}$ stretch from the village of Krasnaia Rechka (adjacent to Khabarovsk) south along the Ussurii River to the small city of Iman. Fifteen million rubles were budgeted for this, over and above the amount going to the trust for strengthening the USSR's western border zone. Though not responsible for supplying itself with a labor force, the trust was ordered to supply daily rations for 3,000 workers per List Number One norms, and for 5,000 at List Number Two levels. It was also to provide manufactures and consumer goods for 8,000 men, along with winter clothing and forage rations for 1,000 horses for eight months.

\section{Commissariat of Posts and Telegraphs}

Communications in the Far East traditionally having been poor, and secure communications nearly nonexistent, the Commissariat of Posts and Telegraphs was ordered to rectify a whole host of problems. This began with five new aboveground telegraph lines connecting out-of-the-way places; burying the existing wires

in Vladivostok, Khabarovsk and Blagoveshchensk; laying cables under the Amur, Zeia, and other major territorial rivers; and replacing old transmission equipment along the telegraph trunk line between Chita and Nikol'sk-Ussuriisk. Communications with troops in the field were to be accomplished innovatively, via a network of 10 short-range radio stations (four by 15 March 1932 and six by 1 August) to be built behind the border at points designated by the military.

\section{Commissariat of Heavy Industry}

By 1 May 1932, the Commissariat of Heavy Industry was ordered to build aviation-gas tanks in five different locations from Irkutsk to Spassk Dal'nyi (near Lake Khanka), and to fill them. For general construction work, it was ordered to release roughly 100,000 metric tons of cement, about 16,000 metric tons of iron, etc., and was given a strict schedule for ensuring their timely arrival in the Far East. Its list of required supplies included technical manpower: 70 construction engineers, 15 electrical engineers, 10 sanitary engineers, and 300 students lifted from senior courses at construction schools. 


\section{Commissariat of Labor}

The Commissariat of Labor was ordered to bring in 20,000 construction workers, their specialties to be negotiated with the Commissariat of Army and Naval Matters. It also was to send in 8,000 unskilled workers for road construction, per agreement with the Central Highway and Vehicle Administration.

\section{Commissariat of Supply}

To sustain the main labor force assigned to the military buildup, the Commissariat of Supply was ordered to feed 35,000 additional persons according to "special list" norms for the next eight and one-half months. It also was directed to provide them with winter clothing, with manufactures, and with consumer goods. Since dray horses needed to eat too, it was told to supply 10,000 forage rations daily for eight months.

\section{Maintenance Services}

Qualitatively as well as quantitatively, the Far Eastern buildup required maintenance support. New or expanded repair facilities for chemical-warfare units, communications equipment, and field engineers were split roughly equally between Irkutsk and Khabarovsk. In addition, a pair of mobile field-engineer repair shops were ordered set up, along with three traveling motor-vehicle service centers and 30 rail cars fitted out for the same purpose.

Prior to the Japanese investiture, special sections of the disingenuously named Irkutsk Mechanical Factory and the Far Eastern Agricultural-Machine Factory in Khabarovsk (founded on the basis of Tsarist arsenals) were responsible for maintaining the weapons and optics of Far Eastern ground troops. The Defense Commission ordered the Supreme Council of the Economy to expand these to handle 12 rifle divisions (2020,000 men) by the end of 1932 and 24 divisions (224,000 men) by the end of 1933 .

As for tanks and other mechanized equipment, it ordered the Central Highway and Vehicle Administration to set up comparable facilities in Irkutsk and Khabarovsk. The former was to be capable of up to 3,000 major overhauls per year, the latter up to 2,500.

The Defense Commission ordered the All-Union United Aircraft-Production Trust (a military enterprise) to prepare a maintenance facility in Irkutsk capable of servicing 50 TB-3 bombers, 100 I-5 biplane fighters and 100 P-5 multipurpose aircraft. It also moved to militarize civil aviation in the Far East, ordering the All-Union Civil-Aviation Fleet to adapt and enlarge its repair facility in Khabarovsk to service 100 I-5 and 100 P-5 planes by 1 June 1932. By the end of 1932, Khabarovsk was to add the capacity to handle 50 TB-3 bombers and 50 MPR-3 scout hydroplanes.

\section{Logistical and Military-Industrial Support}

To support the men and materiel being poured into the Far East, the Defense Commission mandated the foundation of two new military-industrial centers in eastern Siberia. The first of these was to concentrate on metallurgy, the other chemicals. Bulk metal for refashioning into arms and equipment was to come from expanding the Tsarist-era complex at Petrovsk (east of Ulan-Ude). In the spring of 1932 the modestly sized Petrovsk plant was the only operational steel mill in the USSR east of Magnitogorsk in the Urals. Its expanded output was to supply plants capable of producing up to three million machine-gun and one million 500,000 rifle rounds annually, a artillery-shell works with a yearly output of six million casings, a factory for six million detonators, a mine-torpedo workshop, a bomb-casing plant, and a separate assembly facility for the dangerous 
work of putting fuses, casings and explosives together.

Most of these enterprises were to be new. The sole exception was the bomb-casing plant, which was to be created by retooling an existing tube-rolling mill. On the chemical side of things, reconfiguration of an existing nylon plant would produce 15,000 tons of gunpowder a year. Forty thousand tons of high explosives per year would come from a new factory, half of it to be TNT and half the picric acid compound commonly known as lyddite. Finally, the Defense Commission ordered the creation of a lime-chloride plant (the chemical is used for disinfecting and treating water), along with a separate poison-gas factory equipped with a filling station for dispersal canisters.

The Defense Commission's military-production measures did not stop with the eastern Siberian centers. It instructed the Supreme Council of the Economy to build new factories in Krasnoiarsk and Irkutsk (both west of Lake Baikal) so as to provide automotive, mechanical, and woodworking tools to the Far Eastern forces. At the same time it ordered the Supreme Council to reconfigure the even farther-off Novosibirsk agricultural-combine factory for Far Eastern aircraft production, to build a hydroplane factory in Khabarovsk with an annual capacity of 100 MDR-3 and 50 S-62 planes, and to construct storage tanks in the Far East for a reserve of 14,000 tons of gasoline.

The Defense Commission also ordered the construction and/or expansion of shipbuilding facilities capable of providing the fleet-bereft Far Eastern forces with both river and ocean-going vessels. There already were extensive repair facilities at the so-called "Dal'zavod" in Vladivostok (in the late Imperial era, it was the support base for the Pacific Fleet). The Defense Commission commanded the forced expansion of its dry docks and slipways to accommodate the assembly from scratch of nine mid-sized Shuka-class submarines by 1 November 1932. Just north of Khabarovsk, there also was a small repair facility for the flotilla of gunboats and monitors that patrolled the Amur River and its tributaries. This was ordered expanded at crash tempo for submarine construction, and required to assemble three more Shuka boats by 1 November. In addition to these coastal craft, the existing Baltic and Black Sea naval shipyards were enjoined to build 30 midget submersibles for the Far East. These were to be partially disassembled and shipped by rail to the Far East for reassembly at the Dal'zavod and at the Osipov inlet near Khabarovsk.

Finally, in what would turn out to be a hugely consequential step for the Far East, the Defense Commission ordered the creation of an ocean-going fleet. To build it away from the threat of Japanese naval intervention, it provisionally mandated the construction of a major new shipyard on the Amur River at Khabarovsk. The first phase of this facility was to be finished by 1 January 1933, so that six large submarines and three destroyer-leaders could be commissioned that year. By 1 January 1934, all remaining work was to be completed so that another six large submarines, three more destroyer-leaders, and two six-thousand-ton cruisers could be commissioned that year. To be sure, Khabarovsk almost immediately was adjudged too conspicuous and vulnerable a location for such undertakings. The Defense Commission initiative eventually led to the foundation of the city of Komsomol'sk-na-Amure, some 300 river miles further north. ${ }^{9}$

All told, Stalin's immediate military response to the Japanese investiture involved sending roughly 70,000 additional officers and men into the Far East. Including troops stationed in Eastern Siberia (at the time, the Far Eastern Military Region encompassed both the Trans-Baikal and the Far Eastern Territory), this raised the total regional force to somewhere between 100,000 and 2020,000 active-duty men. By the end of 1932, one

\footnotetext{
${ }^{9}$ Politbiuro Defense Commission resolution (13 January 1932), RGVA f. 9 o. 29s d. 165 11. 161-195.
} 
active-duty Red Army soldier in every nine served east of Lake Baikal. The bulk of these men were deployed along the newly important Manchurian border (especially south of Lake Khanka), around Blagoveshchensk, Khabarovsk and Vladivostok, and in the extreme southern tip of the Maritime Province along the old Korean border.

Much of the vacuum created by the troop transfers to the Far East was filled by the formation of four new rifle divisions in the Soviet heartland. These and other such replacement units required a phased, seven percent increase in the overall size of the Red Army proper: from 900,000 men in January 1932 to 935,000 as of 1 May to 906,000 by 1 October. In the USSR of the 1920s and 1930s, boosting the number of men in uniform normally meant increasing the size of the annual fall call-up. However Article 25 of the law on compulsory military service allowed the Commissariat of Army and Naval Matters to recall reserves as needed. To bring the new units up to operational status in the shortest possible time, the Politbiuro Defense Commission authorized the immediate recall of 53,000 rank-and-file soldiers, 12,000 noncoms, and 5,000 officers. ${ }^{10}$ This was aided by changes in the compulsory-service statutes, effective immediately. Article 49 (a) was amended to allow transfers from territorial units to active duty, and article 51 (a) to permit the recall of any service personnel who had been seconded to non-military duty.

Moreover, extra-budgetary assignments in 1932 for the Commissariat of Army and Naval Matters alone were set preliminarily at four hundred twenty-three million five hundred thousand rubles. This sum was equivalent to roughly ten percent of the Soviet Union's direct military expenditures for the year. ${ }^{11}$

\section{Follow up Measures}

Ambitious as this program certainly was, almost before the initial blizzard of Defense Commission orders had been laundered through the usual bureaucratic channels, intelligence reports from Manchuria and from super-spy Richard Sorge in Tokyo suggested that it needed to be augmented. Precisely who worked out the details is unclear - it may have been Gamarnik, or more likely a working team that included at least one representative from the Army General Staff under the nominal umbrella of the Council of Labor and Defense. In any event, a new package of additional measures emerged in April-June 1933. I summarize them here as well.

Already in April, the Politbiuro was growing anxious about the inevitable delays in constructing gun emplacements. Still, on 13 April it ordered an additional four batteries of heavy guns to be emplaced.

\section{Amerika Gulf}

One four-gun $180 \mathrm{~mm}$ open battery by 1 May 1934;

One four-gun $152 \mathrm{~mm}$ battery in temporary positions by 1 May 1933, to be transferred to permanent positions by 1 May 1934 .

\section{Khabarovsk Region}

Two four-gun $152 \mathrm{~mm}$ batteries covering the confluence of the Sungari and Amur Rivers by 1 October 1934. $^{12}$

\footnotetext{
10 The numbers are internally inconsistent: whereas the phase schedule specifies an increase of 60,000 men, the section on recalling reservists adds up to 70,000. Such discrepancies are not uncommon in Soviet bureaucratic paper of the era, which generally needs to be understood as working documents subject to revision and interpretation and amendment.

11 For the total expenditure see "Table 17, Dynamics of 1932 Military Budget (million rubles)" in Stone, Hammer and Rifle, 191.

12 Politbiuro Defense Commission resolution "On The Construction Of Far Eastern Shore Defenses," attachment to protocol 4 point 3 (13 April 1933), RGVA f. 9 o. 36s d. 733 1l. 1-3
} 
Almost exactly four weeks later, on 11 June, the Council of Labor and Defense authorized a significantly more sweeping set of enhancements in a series of resolutions. The first of these involved additional deployments in the Far East. These mainly had to do with increasing the air power committed to the region:

(1) Two heavy air brigades (total of 96 TB-3 heavy bombers, 24 P-6 and two P-5 multi-purpose aircraft) moved into Khabarovsk and Bochkarevo by 20 August 1933;

(2) Two interceptor squadrons (total of 62 I-5 fighters) from the Moscow Military Region into Uglovoe (north of Vladivostok, at the upper end of Amur Bay) by 1 September 1933.

One new air brigade (total 94 planes) to be formed and dispersed between Irkutsk, Verkhne-Udinsk and the Petrovsk military-industrial complex, this to consist of one ground-attack squadron, one fighter squadron, one reconnaissance squadron, and one glider-parachute squadron; Formation of one airborne artillery unit at Chita (eight P-5 multi-purpose planes); Formation of one airborne artillery unit and one airborne cavalry unit (kav. avia-otriad) at Vozdvizhenka (there were two in the USSR, near Cheliabinsk in the Urals and in the Donbass region of the Ukraine; possibly this was an error for Voznesenka, near Novosibirsk).

Strengthening ground-force manpower was confined to:

One light motorized brigade to be formed at Troitsko-Savsk (later Kiakhta; the railroad junction where the Chinese Eastern Railway connected to the Trans-Baikal railroad) by 1 May 1934.

Other military measures were less substantial but aimed directly at interdicting casual cross-border transit: building and arming 1,078 machine-gun bunkers (ognedye sooruzheniia) at likely crossing points by 1 January 1934; bringing the region's armored cars up to full strength (there were 35 on hand and 121 more needed); etc. ${ }^{13}$

What the Council of Labor and Defense self-described as "secondary measures" towards strengthening the Special Far Eastern Army were considerably more consequential in terms of furthering its embedding into the entire fabric of regional development. As a package they illustrate the pervasiveness and scope of the post-Mukden Incident buildup. They testify to the seriousness with which Stalin and his inner-circle advisers approached the crash militarization of a border that had been so unexpectedly imposed on the DVK.

To start with, Commissariat of Heavy Industry (NKTP) capital investment for 1933 was ordered boosted by 23 million, six hundred thousand rubles to cover additional Far Eastern expenditures:

Dal'sel' mash reconstruction (former Khabarovsk arsenal) was to be finished by end of 1934. NKTP funds assigned to this to doubled from 3.6 to 7.2 million rubles, from the SNK reserve fund (a kind of slush fund used by the Politbiuro to fund sensitive, off-budget operations);

Reconstruction of the "Kuibyshev" factory in Irkutsk (an aircraft-engine service facility) to get three million rubles from the SNK reserve fund;

Outlays for the Novo-Spassk cement factory boosted from 10 million rubles to 15 million, charged to the SNK reserve fund, so that the first phase (one million sacks annual production) is finished in the fourth quarter of 1933.

Various fuel-storage facilities totaling nine million rubles, including three million rubles for a 4,000-ton bunker-fuel facility for the Pacific Fleet in Vladivostok; over and above the 19,500 tons of gasoline storage approved by the Politburo, capacity for another 18,000 tons to be added at points agreed on by the Commissariats of Defense and Heavy Industry. This includes five thousand tons of aviation gas, 12 thousand

13 Council of Labor and Defense resolution 44/ss/o, "[Primary] Measures For Strengthening the Special Red-Banner Far Eastern Army”, 11 June 1933, RGVA f. 9 o. 36s d. 733 11. 7-8. 
tons of motor fuel, and one thousand tons of type "O. V." poison gas. The Council of Labor and Defense's Fuel-reserve Committee and the Commissariat of Railroads were to stockpile 30-day supplies of coal on the Omsk, Tomsk, Trans-Baikal and Ussuri Railroads.

In addition, the Commissariat of Heavy Industry was ordered to finish construction of the first phase of the "Ordzhonikidze" oil refinery in Khabarovsk, such that the plant processed 1070,000 tons of oil by 1 May 1934; the Main Highway Administration was ordered to finish construction and equipment of the vehicle-service facilities in Khabarovsk and Irkutsk; the Main Administration of the Civil Air Fleet was given until 1 May 1934 to finish building aircraft-engine repair factory number 83 in Khabarovsk; the Commissariat of Communications was given until 1 January 1934 to finish all 27 of the low-power radio stations called for in 1933.

Finally, various procurement organs and the Council of Labor and Defense's Reserve Committee were enjoined to bring Far Eastern food reserves into line with the growing military and civilian population. By 1 January 1934, they were to create a two-month "carryover reserve" (perekhodiashchii zapas) of foodstuffs and forage for the territory's military units in peacetime and a five-month "mobilization reserve" (mobzapas) for their use during war. Moreover, the Council of Labor and Defense's Procurement Committee was given until 1 January 1934 to raid the nepfond (the Army's theoretically untouchable emergency grain/fodder reserve) for enough grain to build up a three-month cushion in the general territorial supply (including peacetime military consumption). ${ }^{14}$

If these measures weren't enough, the third and most consequential of the 11 June resolutions unambiguously linked the double-tracking of the Far East's main railways to the need to strengthen the logistical support for the region's troop increase. It also explicitly linked the necessary construction to forced labor by GULAG inmates. This is especially significant because the resulting camp system, the main part of which was known as BAMLAG, would by the end of the 1930s metastasize into the single biggest component of the entire Stalinist forced-labor regime. Pace Alexander Solzhenitsyn, this component of the GULAG was not a "human sewer" aimed at pointlessly squandering the lives of putative enemies of the state. Neither was it supply-side, as James Harris (1999) have argued (unconvincingly, in my view) about forced labor in the Urals. Rather, the relevant bureaucracies were tasked with work of "defense significance" (meaning you could be shot for failure to fulfill it) and told explicitly to use prisoner labor in completing it.

On top of resolution 32/ss/o of 27 May 1933 (not actually found by me), ${ }^{15}$ the Council ordered a considerable number of transport-related measures. To begin with, the Commissariat of Defense had decided that the carrying capacity of Far Eastern trunk railroads needed another boost. Thus the Council gave the Commissariat of Railroads 10 days to figure out how to increase the wartime capacity of Far Eastern trunk lines from 24 to 28 pairs of trains per day on double-tracked lines and from 12 to 14 on single-tracked. It also authorized some 25 million rubles' worth of spur construction, mainly connecting coal mines in the Suchan-Artem-Nakhodka area north and east of Vladivostok. Manpower assistance was to be provided by transferring one construction regiment and one mechanized battalion from the Special Railway Corps and assigning them to the Far Eastern Railway Construction Trust (Dal'stroiput').

The Council also ordered the first stages in a pullback from the first stages in building a second Far

\footnotetext{
${ }^{14}$ Council of Labor and Defense resolution 45/ss/o, "Secondary Measures For Strengthening the Special Red-Banner Far Eastern Army", 11 June 1933, RGVA f. 9 o. 36s d. 733 11. 9-12.

15 Not actually unearthed by me. I was only able to deduce some of its contents from references to fulfillment (and some non-fulfillment) in other documents.
} 
Eastern trunk railroad, the Baikal-Amur Main Line or BAM. Knocking ten million rubles off the funds assigned to its construction, it ordered the Unified Main Political Administration (OGPU) to reassign 5,000 prisoners plus their guards and equipment from work on the line. Three thousand of them were to be turned over to Dal'stroi (!) to help the Commissariat of Railroads build the rail line between Romanovka (upper end of Ussurii Bay) and Cape Sysoevo (on the Sea of Japan east of Nakhodka; the terminus actually ended up at Vrangel Inlet on Cape Povorotny, which forms the southern end of Nakhodka Bay). The other two thousand were assigned to dig coal for the Far Eastern railroads.

As for highway construction, the Central Highway and Vehicle Administration was assigned about 20 million rubles' worth of work, roughly $70 \%$ of which involved cut and fill work on a $375-\mathrm{km}$ stretch from the Khabarovsk suburb of Krasnaia Rechka south along the Ussurii River to the small city of Iman. ${ }^{16}$

\section{Forming a Dedicated Military-Industrial Complex}

As noted above, the qualitative side of the Far Eastern buildup demanded first of all the construction of a military-industrial complex capable of maintaining a modern, mobile army and navy. This in turn required infrastructure improvements, particularly in transport. By dramatically altering the scale and pattern of the industrialization drive in the Far East, these imperatives helped change the thrust of regional population politics.

During the initial stages of the Stalin Revolution, the level of industrialization planned for the Far East was modest in comparison to the development contemplated for virtually every other region with a predominantly sedentary population. Almost all of the major massive construction projects (stroiki) of the First Five Year Plan lay elsewhere, as did many of those of secondary and even tertiary rank. A good deal of this had to do with inertia.

NEP-paradigm views of the Far East were well represented in the policy-planning apparatus, where rightists like Rykov continued to push for increased regional exports and Stalinists were unable to counterpoise a clearly articulated vision of their own. While they worked out alternatives, the strategy that had been in place tended to stay in place and development proceeded on an ad hoc basis. ${ }^{17}$ Final resolution of First Five Year Plan targets for the Far East kept being postponed on account of bureaucratic infighting. By 1931 the delays had reached the point that the entire plan was abandoned as a lost cause. After an extensive review, attention was then shifted to preparing the Second Five Year Plan.

If Far Eastern industrialization during the period nominally covered by the First Five Year Plan was primarily export oriented, the direction it took in the Second was completely different. Beginning in 1932, the center of gravity shifted to defense-oriented heavy industry. Exports continued, since the military-industrial buildup required certain technological imports that had to be paid for. However they fell off sharply as regional resources increasingly were allocated to regional needs. This was most immediately significant as far as timber sales abroad, which were cut off altogether at the end of 1933. All timber production that had been earmarked for export was turned over at that time to "the needs of defense, and also of a non-defense character". ${ }^{18}$

The Second Five Year Plan placed particular emphasis on what was called "machine building" (mashinostroenie), a term applied to tank/tractor factories, shipyards, and so on. For 1931, GOSPLAN reckoned capital investment in regional industry at 133 million rubles, of which only $26.6 \%$ went into heavy

\footnotetext{
${ }^{16}$ Council of Labor and Defense resolution 43/ss/o, "Priority Measures For Strengthening the Special Red-Banner Far Eastern Army," 11 June 1933, RGVA f. 9 o. 36 s d. 733 11. 4-6.

17 See GA KhK f. 353 o. 5 d. 71.2

18 Council of People's Commissars resolution 2714-622ss (19 December 1933): GAKhK f. 137 o. 8 d. 4 1. 2.
} 
industry. In 1932, capital investment jumped to 147 million rubles, of which $46.9 \%$ went into heavy industry. In 1934, when efforts to build a military-industrial complex were at their relative maximum, a whopping 84.5 percent of the 334.8 million rubles disbursed by the center for regional industrialization went into heavy industry. ${ }^{19}$ Comprehensive data past 1936 is sketchy at best. However for the remainder of the decade heavy industry continued to absorb well more than half of the Stalinist state's ever-increasing investment in Far Eastern industrialization. All of it was driven by the exigencies of border defense.

Exactly what was and wasn't military in all this is impossible to assess with certainty, since much of the new industry and infrastructure had dual use built in from the start. Tractor plants, for example, could and did turn out tanks and other Army vehicles; refineries that made ordinary gasoline also produced aviation fuel; chemical plants that produced farm fertilizers also made high explosives and poison gas; etc. However detailed study of the one candid capital budget that has come to light suggests that roughly $60 \%$ of the Union-level investment in the Far East in 1934 had direct or semi-direct military significance. This is far higher than is generally recognized, and if true completely shatters the sovietological consensus that the threat posed by Hitler's Germany was what prompted Stalinist armament.

Military considerations affected every major heavy-industrial project in the region: Factory no. 126 at Komsomol'sk, an assembly/service facility for bomber aircraft; further construction of Dal'promstroi, also at Komsomol'sk, a tertiary assembly plant for naval vessels; a massive expansion/conversion of Dal'sel'mash, the Khabarovsk farm-implement factory that had been founded on a Tsarist arsenal and still maintained most of the region's artillery; improvements at Vladivostok's Dal'zavod, another disingenuously named facility that was the main support base for the Soviet Pacific Fleet; etc. For that matter, the two biggest Commissariat of Light Industry projects (Narkom Legprom) also were disguised military ventures that could just as easily have been labeled heavy-industrial projects: remodeling Khabarovsk's Glavupravgrazhvozhdushflot (Main Administration of the Civil Air Fleet) factory no. 83 (which was indeed transferred to the defense section of NKTP in $1935^{20}$ and Avtoremsnabzavod (Auto Repair And Supply factory) No. 5 (which was not) into military assembly/logistics centers.

To finance this military-industrial expansion, the regime relaxed the obsessive (and futile) attempt it was making elsewhere to achieve growth while holding down the domestic money supply. In 1934, the State Bank noted that the Far East had 1.2\% of the Soviet population. Thanks to differentials designed to attract and keep labor, it earned a disproportionate $3.4 \%$ of all wages paid in the Union in the first six months of the year. Though prices of goods and services were high too, they were insufficient to soak up all these rubles and regional trade receipts came to only 2.3\% of the Union total. Even more importantly, the Far East also received no less than $7.1 \%$ of all capital investment - the money for which was provided mainly by printing it. Thanks to these twin financial hemorrhages, the Far East accounted for a whopping $79.3 \%$ of the State Bank's total monetary emissions in the first half of 1934 . Or to put it somewhat differently, the regional buildup was responsible at that time for roughly eight-tenths of the inflation in the entire Soviet money supply. ${ }^{21}$

Financial discipline was much more strictly kept when it came to precious foreign exchange, however, often producing obscure ripple effects from Far Eastern measures elsewhere within the Soviet economy. In March 1934, for example, renewed pressure to reduce Far Eastern dependence on food imports led to the

\footnotetext{
19 GAKhK f. 353 o. 5 d. 7 1. 8.

${ }^{20}$ GAKhK f. 137 o. 8 d. 11.78.

${ }^{21}$ State Bank Deputy Chair G. N. Arkus, report on monetary operations in the Far East: GAKhK f. 1228 o. 1 d. 1921.218.
} 
decision to establish open-ocean fishing off Kamchatka. For this, Soviet steam-powered trawlers would need coal. Unfortunately, there were no ready sources of supply in the proposed base areas on the peninsula and it would take too much time to create stockpiles. Thus the Commissariat of Foreign Trade was authorized to buy 27 thousand tons of Japanese bunker coal for the fisheries at a cost of 135,000 rubles. To pay for it, bacon exports to Europe (!) were ordered boosted from 20-100 tons to 25,000 tons. ${ }^{22}$

Even if 1934 were a somewhat atypical year, it is crystal clear that the industrialization of the Far East from 1932 through the end of the decade was driven largely by border-defense exigencies that consistently overrode other considerations. By extension, so too were the infrastructure improvements necessary to tie the growing regional military-industrial complex together, and to connect it more firmly to the rest of the USSR. So too were the population politics involved in building and maintaining what Stalinist rhetoric (aimed principally at Japan) soon referred to publicly as a mighty "fore-post on the Pacific".

To sum up all this, whatever the imperatives elsewhere in the Soviet Union were for the Stalin Revolution, ultra-secret Politbiuro Defense Commission and Council of Labor and Defense resolutions show that the overwhelming consideration in the Far East was the military-strategic threat posed by Japan in general and Japan in Manchuria in particular. The impetus behind Dal'krai's transformation into a place d'armes fundamentally was reactive rather than proactive. In my opinion, conventional sovietology has this precisely backwards, possibly because of a persistent Eurocentrism, more charitably because the Stalinist state was so good at burying the archival evidence (along with many of the prison laborers) involved in transforming the Far East. Indeed, I argue, further research should eventually prove that the Far East's dramatic militarization was the model or template for similar changes in the west, particularly in the greater Leningrad region and in the Urals. And, I suggest, border-zone militarization also drove the population policies that helped transform the former backwater into the ur-Stalinist province it had become by the end of the 1930s.

\section{References}

Batbayar, T. (2003). The Japanese threat and Stalin's policies towards Outer Mongolia (1932-1939). In L. Narangoa \& R. B. Cribb (Eds.), Imperial Japan and national identities in Asia, 1895-1945 (p. 173). New York: Routledge.

Baron, N. (2008). New spatial histories of 20th-century Russia and the Soviet Union: Exploring the Terrain. Kritika: Explorations in Russian and Eurasian History, 9(2), 433-447.

Harris, J. (1999). The Great Urals: Regionalism and the evolution of the Soviet system. Ithaca: Cornell University Press.

Kvashonkin, A. V. (Ed.). (1999). Sovetskoe rukovodstvo: perepiska. Moscow: ROSSPEN.

Patrikeeff, F. (2010). Railway as political catalyst: The Chinese Eastern railway and the 1929 Sino-Soviet conflict. In B. A. Elleman \& S. F. Kotkin (Eds.), Manchurian railways and the opening of China: An international history (pp. 81-102). Armonk NY: M. E. Sharpe.

Stephan, J. (1994). The Russian Far East: A history. Stanford: Stanford University Press.

Samuelson, L., \& Shlykov, V. V. (2000). Plans for Stalin's war machine: Tukhachevskii and military-economic planning, 1925-1941. Studies in Russian and East European history and society. New York: St. Martin's Press in association with the Centre for Russian and East European Studies, University of Birmingham.

Stone, D. R. (2000). Hammer and Rifle: The militarization of the Soviet Union, 1926-1933. Lawrence KS: University Press of Kansas.

Stoecker, S. W. (1998). Forging Stalin's army: Marshal Tukhachevsky and the politics of military innovation. Boulder, CO: Westview Press.

Voinovich, V. (1987). Moscow 2042. San Diego: Harcourt Brace Jovanovich.

${ }^{22}$ Council of People's Commissars resolution 438/76ss (7 March 1934): GAKhK f. 137 0. 8 d. 4 1. 73. 